\title{
Erasmiana 1986-1988: A Bibliographical Update
}

\author{
ERIKA RUMMEL
}

The past two years have seen the publication of a number of Erasmian texts and translations. The Toronto Collected Works of Erasmus added two volumes to its correspondence series, which now covers the years up to 1521 (vols 7 and 8, trans R.A.B. Mynors, ann P.G. Bieterholz). Two volumes were also added to the literary and educational series (vols 27 and 28, ed. A.H.T. Levi). They contain some of the most famous of Erasmus' writings: The Praise of Folly, The Complaint of Peace, The Education of a Christian Prince, The Ciceronian, Panegyricus, and Julius exclusus (trans and ann B. Radice, M.J. Heath, B.I. Knott). The Paraphrase of Mark (vol 49, trans and ann E. Rummel) appeared in the New Testament series (ed. R.D. Sider), and the Spiritualia series (ed. J. O'Malley) made its debut with a volume containing the Enchiridion and two treatises on contempt of the world and on the Christian widow (vol 66, trans and ann Ch. Fantazzi, E. Rummel, J. Tolbert Roberts). The three-volume set Contemporaries of Erasmus: A Biographical Register of the Renaissance and Reformation (eds P.G. Bietenholz and Th. A. Deutscher) is now complete.

The most recent additions to the Amsterdam Opera omnia are volume 5-3 (with contributions by A.G. Weiler, R. Stupperich, and C.S.M. Rademaker), which brings to a conclusion the series of Psalm commentaries and volume 2-4 (edited by F. Heinimann and E. Kienzle), which contains adages 1501-1999. A facsimile edition of Erasmus' Annotations on the New Testament (London: Duckworth 1986), edited by A. Reeves and M. Screech, and one of the Novum Instrumentum (1516), edited by H. Holeczek (Stuttgart: Frommann-Holzboog 1986) were reviewed in Erasmus in English 15 (1987-8) 25-27.

A previously unknown letter by Erasmus was discovered in the Herzog August Bibliothek in Wolfenbuttel, Germany. The text is published by E. Rummel in 'Ein unbekannter Brief von Erasmus an Christoph Truchsess 
Baron von Waldburg' Wolfenbütteler Renaissancemitteilungen 12 (1988) 101-2. Two letters from Ferdinand of Habsburg to Erasmus in the Haus-, Hof- und Staatsarchiv in Vienna, the text of which appeared first in the doctoral thesis of $\mathrm{H}$. Eberdorfer, are reproduced and translated by J.-C. Margolin in Erasmus of Rotterdam: The Man and the Scholar (see below). The Latin text of two letters from Erasmus to Joannes Sapidus and Eobanus Hessus respectively appeared in print for the first time in C.M. Bruehl's 'Zwei unbekannte Briefe von Erasmus' Quaerendo 16-4 (1986) 243-58. Readers may recall another recent discovery: a letter from Erasmus to Hutten that came to light in the Archivio di Stato in Florence and was published by P.O. Kristeller in Tradizione classica e letteratura umanistica (Rome 1985). Kristeller's article contains a list of Erasmian letters discovered since the publication of Allen's Opus epistolarum (Oxford 1906-58).

A number of collections of essays and papers have appeared during the past two years. El Erasmismo en España (Santander: Sociedad Menendez Pelayo 1986) records the proceedings of a conference held at the Biblioteca de Menendez Pelayo in 1985 (edited by M. Revuelta Sañudo and C. Morón Arroyo). It is an important complement to Marcel Bataillon's classic study Erasme et Espagne, which is given its proper place in the history of Erasmian scholarship in M. Revuelta Sañudo's and D. Devoto's prefatory pieces. Other contributions to the volume discuss the fortuna of Erasmus' works in Italy (S. Seidel-Menchi), his biblical scholarship, and the controversies generated by his edition of the New Testament (N. Fernández Marcos and E. Fernández Tejero, M. Avilés Fernández, M.A. Pérez Priego). Of special interest in this context is Carlos Gilly's article concerning a recently discovered polemic against Erasmus and Reuchlin by Elio Nebrija, the text of which is printed here for the first time. Individual Erasmian works - his style manuals, the Apophthegmata, and De contemptu mundi - are discussed in articles by A. Cilveti Lecumberri, E. Llamas Martínez, and L. López Grigera. Erasmus' influence on the spiritual and intellectual life of Spain is traced by M. Andrés Martín, J. Pérez, A. Huerga, A. Delgado Gómez, and F. López Estrada. Spanish humanists and theologians who came into contact with Erasmus and his writings are discussed by C. García Gual (on Antonio de Guevara), A. Alvar Ezquerra (on Alvar Gómez de Castro), B. Monsegú and E. Rivera de Ventosa (on Vives), M. Firpo, M. Morreale, D. Briesemeister, F. Abad, J.V. Ricapito (on Juan and Alfonso Valdés). Broader topics are dealt with by C. Morón Arroyo ('El sistema de Erasmo'), V. Muñoz Delgado ('Nominalismo, Logica y humanismo'), T. de Azcona ('El hecho episcopal hispánico en 
tiempo de Carlos V'), V. Pinto Crespo ('La herejia como problema político') and J.I. Tellechea Idigoras ('El Protestantismo castellano').

Classical and Modern Literature devoted its 1987 issue (edited by Jane E. Phillips) to Erasmus. It contains articles on recent editions and translations of Erasmus' works (D. Bundy), on Erasmus in England (R.J. Schoeck), and on various aspects of his works (Copia: A. Vos, Colloquies: M. Bromley, Annotations: E. Rummel, editions of Seneca: L.A. Panizza).

The Colloque Erasmien de Liège (Paris: Edition 'Les Belles Lettres' 1987), dedicated to L.-E. Halkin, consists of two parts, the first containing three essays by S. Dresden ('Erasme et les belles-lettres'), M.M. Phillips ('Visages d'Erasme'), and S. Seidel Menchi ('Erasme et son lecteur'). The second part concentrates on Erasmus as theologian and biblical scholar and contains contributions by C. Augustijn ('Erasmus und seine Theologie'), Charles Béné ('Saint François de Sales et Erasme'), J. Chomarat ('Sur Erasme et Origène'), R. Crahay ('Le procès d'Erasme à la fin du XVI siècle. Position de quelques jésuites'). M.M. de la Garanderie ('Erasme et Luther commentateurs de la première épitre de saint Jean'), R.L. DeMolen (on Erasmus' philosophia Christi), E.W. Kohls ('Die Neuentdeckung der Theologie des Erasmus'), R. Padberg (on Erasmus' concept of the just war), E.V. Telle (Erasmus on matrimony and virginity). Miscellaneous topics are discussed by M. Cytowska ('De l'Episode polonais aux comédies de Térence'), O. Herding ('Erasmische Friedensschriften im 17. Jahrhundert'), J.-C. Margolin ('Les "Erasmiana" de l'Abbé Raymond Marcel'). Special mention should be made of texts published here for the first time: four letters from Erasmus' adversary J. Stunica to Pope Leo X (ed H.J. De Jonge).

In 1988 the Wolfenbütteler Abhandlungen zur Renaissanceforschung published volume 7, Erasmus und Europa (ed. A. Buck), which contains articles on Erasmus and the Netherlands (L.-E. Halkin), France (J.-C. Margolin), Spain (D. Briesemeister), England (H. Schulte-Herbrüggen), and Hungary (A. Ritook-Szalay), as well as articles on miscellaneous topics by $O$. Herding ('Erasmus - Frieden und Krieg'), P.G. Schmidt ('Erasmus und die Mittellateinische Literatur'), B. Haegglund ('Erasmus und die Reformation'), M. Knops (on a German translation of the adage Aut regem aut fatuum nasci oportet) and C. Reedijk ('The Leiden Edition of Erasmus' Opera Omni in a European Context').

Dix Conferences sur Erasme (Paris-Geneva: Champion-Slatkine 1988) records the proceedings of a conference organized by the University of Basel at the Centre Culturel Suisse in Paris, 1986. The volume contains papers dealing with two Erasmian works, the Praise of Folly and the 
Colloquies, a preface by L.-E. Halkin, and concluding remarks by J.-C. Margolin. Contributors are Marc Fumaroli ('L'éloquence de la Folie'), Marcel Tetel ('L'Eloge de la Folie: Captatio Benevolentiae'), J. Chomarat ('L'Amour dans L'Eloge de la Folie et les Colloques'). Various aspects of the Colloquies are examined by E. Kushner (on argumentation in utramque partem), J.-C. Margolin (on rhetorical techniques in the colloquy 'Echo'), F. Bierlaire ('La première edition falsifiée des Colloques'), R. Hoven (Le Conflictus Thaliae et Barbariei: un Colloque d'Erasme?'); Charles Béné and A. Godin on two controversial colloquies, 'Naufragium' and 'Peregrinatio religionis erga,' and A. Chastel on Erasmus, 'L'ennemie de la magnificence.'

The proceedings of the Erasmus Symposium held in Rotterdam in 1986 have appeared under the title Erasmus of Rotterdam: The Man and the Scholar (Leiden: Brill 1988), eds J. Sperna Weiland and W.Th.M. Frijhoff. The book is divided into three sections, with individual introductions by the editors, entitled 'Power Relations,' 'Education and the World of Learning,' and 'Images.' The first section, which deals with Erasmus' relationship with secular and ecclesiastical powers, contains essays on Erasmus and the bishop of Cambrai (R.J. Schoeck), Ferdinand of Habsburg (J.-C. Margolin, mentioned above), and the Fifth Lateran Council (N.H. Minnich); on Erasmus' counsel on the Turkish campaign (A.G. Weiler), his views on the subject of communal goods (M. Isnardi-Parente), his controversies with Latomus, the Spanish Orders, and Alberto Pio (M. Gielis, E. Rummel, C.L. Heesakers), and his last will (P.P.J.L. Van Peteghem). In the second section, dealing with learning and education, we find essays on some of Erasmus' educational writings (M. Marin, J.K. Sowards, B.I. Knott), on Erasmus as a translator and textual critic (B. and E. Ebels, H. de Jonge, D.F.S. Thomson), as a commentator on his times (G. Chantraine), and on Erasmus and his friends and correspondents (J. den Boeft, J. Olin, C.S.M. Rademaker). The third section offers three interpretations of Erasmus. C. Augustijn concentrates on Erasmus' image in Germany; B. Mansfield offers a study of Erasmus' image as a champion of moderation and tolerance; and N. Van der Blom contributes some interesting examples of 'Erasmus-promotion' in Holland.

Three other collections are for the most part reprints. Marie Delcourt's Erasme (Brussels: Editions Labor 1986), with a preface by P. Jodogne and a brief bibliographical essay by F. Bierlaire, contains articles first published in 1944 and one previously unpublished piece, 'Histoire d'un livre: Les Colloques.' J.-C. Margolin's Erasme: le prix des mots et de l'homme (London: Variorum Reprints 1986) presents essays from the years 1964-84. 
R.L. DeMolen's The Spirituality of Erasmus (Nieuwkoop: De Graaf 1987) contains reprints of articles published between 1971 and 1987, with a new contribution 'The Expression of Love in the Oeuvre of Erasmus.'

The proceedings of the Neo-Latin conference held at Wolfenbuttel in 1985, Acta Conventus Neo-Latini Guelpherbytani, eds St. Revard, F. Radle, M. DiCesare (Binghampton, NY: 1988), contain three papers of special interest to Erasmians: C.H. Hiller's 'Styles and Mixed Genres in Erasmus' Praise of Folly,' L. Beck's 'Thomas More on the Double Portrait of Erasmus and Pierre Gillis,' and H. 'Schulte-Herbrüggen's 'Artes dictandi und erasmische Theorie in More's lateinischen Briefen.'

The Erasmus of Rotterdam Society Yearbook, devoted exclusively to articles on Erasmus and now in its eighth year, has announced a new feature. It endeavours to publish short monographs on Erasmus, the first of which appeared in its 1986 issue: 'A Study of the Collaboration between Erasmus of Rotterdam and His Printer Johann Froben ...,' by S.D. Shaw.

Other monographs on Erasmus published during the past two years are: Friedhelm Krüger's Humanistische Evangelienauslegung (Tübingen: Mohr 1986), which examines Erasmus' Paraphrases; E. Rummel's Erasmus' Annotations on the New Testament: From Philologist to Theologian (Toronto: University of Toronto Press 1986), which examines the genesis, sources, and contents of the Annotations; S. Seidel Menchi's Erasmo in Italia, 1520-1580 (Turin: Bollati Boringhieri 1987), which deals with inquisitorial processes involving Erasmus' works in 16th-century Italy; R.J. Schoeck's Erasmus Grandescens: The Growth of a Humanist's Mind and Spirituality (Nieuwkoop: De Graaf 1988), which examines Erasmus' spiritual and intellectual development from his days in the school of the Brethren of the Common Life at Deventer to the first publication of The Praise of Folly. Two comprehensive biographies have also appeared recently: L.-E. Halkin's Erasme (Paris: Fayard 1988) and C. Augustijn's Erasmus von Rotterdam: Leben-Werk-Wirkung (Munich: Beck 1986), which is also available in the Dutch original (Baarn: Ambo 1986) and which will appear in English in 1990 as Erasmus: His Life, Works, and Influence, published by University of Toronto Press. A thumbnail sketch of Erasmus' life and works is offered by E. Campion in Critical Survey of Literary Theory (Pasadena: Salem Press 1988) 467-72. A chapter is also devoted to Erasmus in Renaissance Humanism: Foundations, Forms, and Legacy, ed A. Rabil Jr (Philadelphia: University of Pennsylvania Press 1988), vol II 216-264.

Among articles published during the period in consideration the following have been brought to our attention: 
R. Baldwin 'Peasant Imagery and Bruegel's "Fall of Icarus"' Konsthistorisk Tidskrift 15 (1986) 101-14

J. Berchtold 'Le poète-rat: Villon, Erasme, ou les secrètes alliances de la prison dans l'épître "A son amy Lyon" de Clement Marot' Bibliothèque d'Humanisme et Renaissance 50 (1988) 57-76

P.G. Bietenholz “"Haushalten mit der Wahrheit": Erasmus im Dilemma der Kompromissbereitschaft' Basler Zeitschrift für Geschichte und Altertumskunde 86 (1986) 476-506

A. Breeze 'Leonard Cox, a Welsh Humanist in Poland and Hungary' The National Library of Wales Journal 25-4 (1988) 399-410

J. Chomarat 'Erasme et Platon' Bulletin de l'Association G. Budé 1 (1987) 25-45

J. Chomarat 'Diable, Diables et Diableries au temps de la Renaissance' Publications of the Centre de Recherches sur la Renaissance 13 (1988) 131-47

Ch. Christ-von Wedel 'Das "Lob der Torheit" des Erasmus von Rotterdam im Spiegel der spätmittelalterlichen Narrenbilder und die Einheit des Werkes' Archive for Reformation History 78 (1987) 24-36

R. Coogan 'The Pharisee Against the Hellenist: Edward Lee Versus Erasmus' Renaissance Quarterly 89 (1986) 476-506

M. Cytowska 'L'Eloge de la Paix depuis Erasme jusqu'à Jan Kochanowski’ Eos 75 (1987) 401-411

H.J. de Jonge 'The Date and Purpose of Erasmus' Castigatio Novi Testamenti: A note on the Origins of the Novum Instrumentum' in The Uses of Greek and Latin (London: Warburg Institute 1988)

'Erasmus' Method of Translation in his Version of the New Testament' The Bible Translator 37-1 (1986) 135-38

J.W. O'Malley 'Grammar and Rhetoric in the Pietas of Erasmus' The Journal of Medieval and Renaissance Studies 18 (1988) 81-98

J. Phillips 'Erasmus, Cyril, and the Annotationes on John' Bibliothèque d'Humanisme et Renaissance 50 (1988) 381-84 
C. Reedijk 'Festina lente Nocheinmal: Johan Huizinga, Werner Kaegi und ihr Erasmus' Het oude en het nieuwe boek. De oude en de nieuwe bibliotheek Kapellen 1988

E. Rummel 'An open letter to boorish critics: Erasmus' Capita argumentorum contra morosos quosdam ac indoctos' Journal of Theological Studies 39 (1988) 438-59

'Nameless Critics in Erasmus' Annotations on the New Testament' Bibliothèque d'Humanisme et Renaissance 48 (1986) 41-57

R.D. Sider 'Xá $\epsilon$ 's and Derivatives in the Biblical Scholarship of Erasmus' in Diakonia (Washington: Catholic University Press 1986) 242-60

J. Trapman 'Il Testo originale e la traduzioni' in Il Sommario della Santa Scrittura (Turin: Claudiana 1988) 7-23

H. Vredeveld 'An Obscure Allusion in Erasmus' Ode on St Michael' Bibliothèque d'Humanisme et Renaissance 48 (1986) 91-92

'The Philological Puzzles in Erasmus' "Poem on Old Age"' Bibliothèque d'Humanisme et Renaissance 49 (1987) 597-604 